\title{
Impact of parametric uncertainties on the present-day climate and on the anthropogenic aerosol effect
}

\author{
U. Lohmann and S. Ferrachat \\ Institute of Atmospheric and Climate Science, ETH Zurich, Switzerland \\ Received: 30 June 2010 - Published in Atmos. Chem. Phys. Discuss.: 13 August 2010 \\ Revised: 19 November 2010 - Accepted: 22 November 2010 - Published: 1 December 2010
}

\begin{abstract}
Clouds constitute a large uncertainty in global climate modeling and climate change projections as many clouds are smaller than the size of a model grid box. Some processes, such as the rates of rain and snow formation that have a large impact on climate, cannot be observed. The uncertain parameters in the representation of these processes are therefore adjusted in order to achieve radiation balance. Here we systematically investigate the impact of key tunable parameters within the convective and stratiform cloud schemes and of the ice cloud optical properties on the present-day climate in terms of clouds, radiation and precipitation. The total anthropogenic aerosol effect between preindustrial and present-day times amounts to $-1.00 \mathrm{~W} \mathrm{~m}^{-2}$ obtained as an average over all simulations as compared to $-1.02 \mathrm{~W} \mathrm{~m}^{-2}$ from those simulations where the global annual mean top-of-the atmosphere radiation balance is within $\pm 1 \mathrm{~W} \mathrm{~m}^{-2}$. Thus tuning of the present-day climate does not seem to have an influence on the total anthropogenic aerosol effect. The parametric uncertainty regarding the above mentioned cloud parameters has an uncertainty range of $25 \%$ between the minimum and maximum value when taking all simulations into account. It is reduced to $11 \%$ when only the simulations with a balanced top-of-the atmosphere radiation are considered.
\end{abstract}

\section{Introduction}

Uncertainties in climate change projections stem from uncertainties in emission scenarios, structural uncertainties that measure the range of the mean responses in different models,

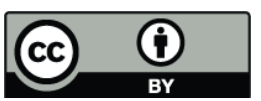

Correspondence to: $\mathrm{U}$. Lohmann (ulrike.lohmann@env.ethz.ch) internal variability and parametric uncertainties that are induced by uncertainties in the model parameters (Cox and Stephenson, 2007; Hawkins and Sutton, 2009). These cited studies showed that at the beginning of a climate simulation the internal variability dominates the overall uncertainty in climate change projections. As the internal variability reduces with time of projection, the total uncertainty decreases. After some decades the total uncertainty increases again caused by the increase in the scenario uncertainty.

The scenario uncertainty increases with time of climate projections into the future because the scenarios depend on the demographic evolution, socio-economic development and technological changes and renovations. In terms of aerosols and aerosol-cloud-interactions since pre-industrial times the scenario uncertainty is caused by the different preindustrial and present-day aerosol emission data sets. Nowadays most of the aerosol community uses the AEROCOM emissions representative for the year 1750 and for the year 2000 (Dentener et al., 2006). Nevertheless, uncertainties remain regarding for instance anthropogenic dust sources as it is not clear how important they are (Denman et al., 2007) or the question as to how much biomass burning can be considered natural and to have been there in pre-industrial times.

The structural uncertainty stems from different schemes or approaches used in different climate models. In terms of the anthropogenic aerosol effect, these are given by the complexity of the aerosol model, the cloud microphysics scheme and interactions between the two. State-of-the-art aerosol models solve prognostic equations for at least the mass mixing ratios of the major aerosol species sulfate, black and organic carbon, e.g. Koch et al. (2009); Rotstayn et al. (2007). Some models additionally solve prognostic equations for the number mixing ratios of the different aerosol compounds, and predict their mixing state, e.g. Stier et al. (2005); Wang and Penner (2009). The simplest way and oldest approach to

Published by Copernicus Publications on behalf of the European Geosciences Union. 
account for aerosol-cloud interactions is to use empirical relationships between the aerosol mass and the cloud droplet number concentration (Boucher and Lohmann, 1995; Jones et al., 2001). Since then physically-based parametrizations have been developed (Abdul-Razzak and Ghan, 2000; Fountoukis and Nenes, 2005; Ming et al., 2006) and are used in several global climate models (GCMs), e.g. (Takemura et al., 2005; Ghan and Easter, 2006; Ming et al., 2007; Bauer et al., 2008; Suzuki et al., 2008; Storelvmo et al., 2008; Pringle et al., 2009; Salzmann et al., 2010).

A large structural uncertainty related to the anthropogenic aerosol effect is caused by the representation of clouds in climate models as many clouds are smaller than the size of a model grid box. Also cloud microphysical processes occur on the subgrid scale and need to be parameterized. These days most cloud microphysics schemes solve at least one prognostic equation for the cloud condensate whereas more complex schemes distinguish between water and ice and also predict the number concentrations of cloud droplets and ice crystals (Ghan et al., 1997a,b; Lohmann et al., 2007; Morrison and Gettelman, 2008; Salzmann et al., 2010) or solve prognostic equations also for the mass mixing ratios of rain and snow (Fowler et al., 1996). Some processes, such as the rain and snow formation rates, cannot be observed and are thus rather uncertain. As the rain and snow formation rates have a large impact on cloud water and ice and hence the planetary energy balance, parameters used to represent them are used to tune the model in order to achieve radiation balance. This means that the precipitation formation rates are enhanced or decelerated in order to yield a top-of-the atmosphere (TOA) radiation budget that is balanced to within $1 \mathrm{~W} \mathrm{~m}^{-2}$ and that the individual radiative fluxes agree within $5 \mathrm{~W} \mathrm{~m}^{-2}$ with the fluxes estimated from satellite data. There has been some discussion if the net TOA radiation balance should be close to zero or should be positive because of the delayed warming in the ocean in response to the greenhouse gas forcing. This imbalance is estimated at $0.85 \mathrm{~W} \mathrm{~m}^{-2}$ for the period 1993-2003 (Hansen et al., 2005). In case that atmospheric GCMs are driven with the observed transient greenhouse gas concentrations and sea surface temperatures (so-called AMIP simulations), they need to be tuned with a positive TOA radiation balance to take the imbalance into account. If, on the other hand, atmospheric GCM simulations are conducted with climatological sea surface temperature and greenhouse gas concentrations that correspond to each other, tuning the atmospheric GCM to give a radiation balance close to zero $\mathrm{W} \mathrm{m}^{-2}$ is desirable for comparison with observations and also for coupling the atmospheric GCM to an ocean model.

Uncertainties in the first indirect aerosol effect by anthropogenic sulfate aerosols were first investigated by Pan et al. (1998). The first indirect aerosol effect or cloud albedo effect refers to an increase in cloud albedo due to more and smaller cloud droplets formed on the larger number of anthropogenic aerosols when keeping the liquid water content constant (Twomey, 1977). The cloud albedo effect is evaluated as the difference between pre-industrial times and the present-day. Pan et al. (1998) obtained a structural uncertainty of $0.5 \mathrm{~W} \mathrm{~m}^{-2}$ (range between -1.2 and $-1.7 \mathrm{~W} \mathrm{~m}^{-2}$ ). In the Forth Assessment Report (AR4) of the Intergovernmental Panel of Climate Change (IPCC), the median value of the cloud albedo effect from pre-industrial times to the present-day was estimated as $-0.7 \mathrm{~W} \mathrm{~m}^{-2}$ (Forster et al., 2007). The structural uncertainty was evaluated as the 5 to 95\% range between the different estimates and amounted to -0.3 to $-1.8 \mathrm{~W} \mathrm{~m}^{-2}$ (Forster et al., 2007). Storelvmo et al. (2009) compared four different empirical relationships between cloud droplet number concentration and aerosol mass that have been used in the transient simulations of the IPCC AR4 report (Meehl et al., 2007). Storelvmo et al. (2009) applied these different relationships within the EC-Earth GCM showing that this leads to a spread of $1.3 \mathrm{~W} \mathrm{~m}^{-2}$ in terms of the cloud albedo effect. On the other hand, if aerosol concentrations, the parameterization of droplet concentrations and the autoconversion rate, that describes the rate by which cloud droplets collide to form rain drops, are all specified the same in different GCMs then the predicted cloud albedo effect varies only between -0.6 to $-0.7 \mathrm{~W} \mathrm{~m}^{-2}$ in different GCMs, thus reducing the structural uncertainty to $0.1 \mathrm{~W} \mathrm{~m}^{-2}$ (Penner et al., 2006).

Feedbacks due to the cloud lifetime effect, semi-direct effect or aerosol effects on mixed-phase and ice clouds can either enhance or reduce the cloud albedo effect. As shown by Penner et al. (2006) if only the aerosol emissions are prescribed in different GCMs, but the GCMs are free in the way they account for cloud droplets and the autoconversion rate, then the structural uncertainty of total indirect aerosol effects increases from the $0.1 \mathrm{~W} \mathrm{~m}^{-2}$ mentioned above to $1.1 \mathrm{~W} \mathrm{~m}^{-2}$. If the GCMs are also free to choose their emission data base, then the whole structural uncertainty of the aerosol radiative effects can be compared. As aerosols are radiatively active in most GCMs, most GCMs that evaluate changes between pre-industrial and present-day times also include estimates of the direct aerosol effect. Evaluation of the total anthropogenic aerosol effect (sum of direct effect, cloud albedo effect and other aerosol-cloud effects) in the IPCC AR4 report was thus found to be $-1.2 \mathrm{~W} \mathrm{~m}^{-2}$ ranging from -0.2 to $-2.3 \mathrm{~W} \mathrm{~m}^{-2}$ (Denman et al., 2007).

Estimates of the cloud albedo effect alone and of the total anthropogenic aerosol effect have become less negative with time of publication (Lohmann et al., 2010). The least square fit line of the total anthropogenic aerosol effect approaches $-1.2 \mathrm{~W} \mathrm{~m}^{-2}$ in publications of the year 2009. Since some newer studies that were not considered in IPCC AR4 obtained a rather large negative effect, while another found a small positive effect, the structural uncertainty evaluated as the total range in estimates of the total anthropogenic aerosol effect increased to $3.5 \mathrm{~W} \mathrm{~m}^{-2}$ (range from +0.1 to $-3.4 \mathrm{~W} \mathrm{~m}^{-2}$ ). 
The parametric uncertainty has received more attention in recent years. Murphy et al. (2004) investigated the parametric uncertainty for climate change simulations by varying six cloud parameters. A huge ensemble of multi-thousand members was conducted within the climate-prediction.net framework where initial conditions and parameter values were systematically varied (Piani et al., 2005). In terms of the cloud albedo effect, the parametric uncertainty was investigated by Pan et al. (1998). They obtained a huge range of the cloud albedo effect from -0.1 to $-5.2 \mathrm{~W} \mathrm{~m}^{-2}$ suggesting that the parametric uncertainty exceeds the structural uncertainty. Haerter et al. (2009) used the ECHAM5 GCM to estimate the parametric uncertainty of the direct aerosol effect plus the cloud albedo effect from sulfate aerosols. They found that the uncertainty due to a single investigated parameter can be as large as $0.5 \mathrm{~W} \mathrm{~m}^{-2}$, and the uncertainty due to combinations of these parameters can reach more than $1 \mathrm{~W} \mathrm{~m}^{-2}$ for a central estimate of the direct effect plus cloud albedo effect from sulfate aerosols of $-1.9 \mathrm{~W} \mathrm{~m}^{-2}$ obtained with their model set-up.

In this paper we investigate the parametric uncertainty of tunable parameters related to key cloud processes and radiative properties in terms of the present-day climate and for the total anthropogenic aerosol effect between pre-industrial times and the present-day. The paper has two purposes. It seeks to evaluate how the tuning of the key cloud parameters affects the present-day climate and if it affects the climate beyond the quantities it immediately controls. Moreover we want to investigate if the tuning of the global-mean presentday climate has implications for the anthropogenic aerosol effect.

Whereas the studies by Pan et al. (1998) and Haerter et al. (2009) evaluated the parametric uncertainty only for the direct aerosol effect and for a simple estimate of the cloud albedo effect in response to sulfate aerosols, here we also take the fast feedbacks (Lohmann et al., 2010), such as the cloud lifetime effect, the semi-direct effect and aerosol effects on mixed-phase and ice clouds, from the three major anthropogenic aerosols (sulfate, black carbon and organic carbon) into account. Pan et al. (1998) used a globalaverage box model while Haerter et al. (2009) used prescribed monthly mean mass mixing ratios of sulfate aerosols, which are empirically related to the cloud droplet number concentration. In this study, aerosol mass and number concentrations are calculated on-line and act as cloud condensation and ice nuclei. Thus, the estimates of the parametric uncertainty on the total anthropogenic aerosol effect in this paper are based on advanced aerosol-cloud microphysics interactions.

\section{Model description}

The version of ECHAM5-HAM used in this study has been described in Lohmann and Hoose (2009). It includes the two-moment aerosol scheme HAM that predicts the aerosol mixing state in addition to the aerosol mass and number concentrations (Stier et al., 2005). The size-distribution is represented by a superposition of log-normal modes including the major global aerosol compounds sulfate, black carbon, organic carbon, sea salt and mineral dust. Updates to the aerosol scheme are briefly mentioned in Lohmann and Hoose (2009). They include the aerosol-size dependent belowcloud scavenging by Croft et al. (2009), water uptake by aerosols following Petters and Kreidenweis (2007) and a revised aerosol nucleation scheme (Kazil and Lovejoy, 2007).

The stratiform cloud scheme consists of prognostic equations for the water phases (vapor, liquid, solid), bulk cloud microphysics (Lohmann and Roeckner, 1996), and an empirical cloud cover scheme (Sundqvist et al., 1989). The microphysics scheme includes phase changes between the water components and precipitation processes (autoconversion, accretion, aggregation). Moreover, evaporation of rain and melting of snow are considered, as well as sedimentation of cloud ice. It also includes prognostic equations of the number concentrations of cloud droplets and ice crystals and has been coupled to the aerosol scheme HAM (Lohmann et al., 2007). Cloud droplet activation is empirically linked to the aerosol number concentration and the subgrid-scale updraft velocity (Lohmann et al., 2007). Cirrus clouds are assumed to form by homogeneous freezing of supercooled solution droplets (Lohmann et al., 2008), which is the dominant freezing mechanism for cirrus clouds (Kärcher and Ström, 2003).

We assume that internally mixed dust and $\mathrm{BC}$ aerosols act as immersion nuclei while externally mixed dust particles act as contact nuclei (Hoose et al., 2008b). The parameterizations of immersion and contact freezing are based on those described in Lohmann and Diehl (2006). In addition we now also account for contact freezing by thermophoresis (Lohmann and Hoose, 2009).

\section{Set-up of the simulations}

The ECHAM5 simulations have been carried out in T42 horizontal resolution $\left(2.81^{\circ} \times 2.81^{\circ}\right)$ on 19 vertical levels with the model top at $10 \mathrm{hPa}$ and a timestep of $30 \mathrm{~min}$. All simulations used present-day climatological (average over the years 1956-1999) sea surface temperature and sea-ice extent. The simulation conducted to investigate the parameter space for the present-day climate have been integrated for one year after a 3 months spin-up. This simulation time would be too short to compare geographical features of the simulations to observations. However, based on our experience one year is sufficient in order to evaluate the global annual mean radiation balance at the top-of-the atmosphere (TOA), which 
is the goal of this study. This is justified by the small yearto-year variability of the net TOA radiation that amounts to a standard deviation of $0.2 \mathrm{~W} \mathrm{~m}^{-2}$ as obtained from two 10year simulations. These simulations will be referred to as climate or free simulations. The greenhouse gas concentrations are constant and correspond to values around 1985. They are consistent with our climatological sea surface temperature so that we tune the model to yield a near $0 \mathrm{~W} \mathrm{~m}^{-2}$ radiation balance.

The simulations conducted to obtain the total anthropogenic aerosol effect (both for the present-day (PD) and for pre-industrial times (PI)) have been nudged to the ECMWF ERA40 reanalysis data (Simmons and Gibson, 2000) for the year 2000 so that changes in meteorology are minimized between the different simulations. Nudging ensures that the dust and sea salt emissions which depend on wind speed are comparable in the pre-industrial and present-day climate. These simulations also use present-day climatological sea surface temperature and sea-ice extent. Lohmann and Hoose (2009) compared estimates of the total anthropogenic aerosol effect between a nudged version and a 10-year free simulations and found that to be comparable. I.e. nudged simulations can be used to evaluate the total anthropogenic aerosol effect. This saves a lot of CPU time. The nudging time scales are $6 \mathrm{~h}$ for vorticity, $24 \mathrm{~h}$ for the logarithms of the surface pressure and temperature and $48 \mathrm{~h}$ for the divergence. Nudging can, however, not be used to tune the model to the present-day climate, because it changes the model climate. The nudged simulations have a higher convective activity and convective precipitation and a smaller shortwave cloud forcing (not shown). Thus, simulations that have a balanced TOA radiation budget in free mode can have a radiation imbalance of several $\mathrm{W} \mathrm{m}^{-2}$ when run in nudged mode.

The present-day simulations use aerosol emissions of sulfate, black and organic carbon from the AEROCOM data base for the year 2000 (Dentener et al., 2006). Mineral dust and sea salt emissions are calculated based on wind speed within the model. To isolate the total anthropogenic aerosol effect, all simulations were repeated with aerosol emissions of sulfate, black and organic carbon for pre-industrial times representative for the year 1750 (Dentener et al., 2006).

In order to investigate the parametric uncertainty we varied those parameters that are typically used to ensure radiation balance at TOA in the present-day climate. These include the rate of rain formation by autoconversion $\left(\gamma_{r}\right)$, the rate of snow formation by aggregation $\left(\gamma_{s}\right)$, the inhomogeneity factor of ice clouds $\left(\gamma_{i}\right)$ and the entrainment rate into deep convective clouds $(\epsilon)$. We chose those four parameters because they are the ones that are modified when the cloud microphysics scheme is improved. If the goal of the tuning is just to have a TOA net radiation balance between $\pm 1 \mathrm{~W} \mathrm{~m}^{-2}$ and to ensure that the longwave and shortwave cloud forcing are within $5 \mathrm{~W} \mathrm{~m}^{-2}$ of the observations, it would be sufficient to tune two parameters. Therefore the focus of tuning of the model is placed on tuning the autoconversion and aggrega- tion rates. However, when tuning the model we also seek guidance from observations of the liquid water path and total cloud cover such that we prefer simulations in which the liquid path lies between 50 and $84 \mathrm{~g} \mathrm{~m}^{-2}$ over the oceans (Ferraro et al., 1996; Greenwald et al., 1993; Weng and Grody, 1994) and that the total cloud cover is between $62 \%$ and $75 \%$. (Hahn et al., 1994; Rossow and Schiffer, 1999; King et al., 2003; Stubenrauch et al., 2009). In order to match these four quantities at least four tuning parameters are necessary. More than four tuning parameters would mean that the system is over-determined. Therefore we restrict ourselves to these four tuning parameters.

The parameterizations of the autoconversion and aggregation rate used in ECHAM5 are taken from those derived from cloud resolving models (CRM) (Khairoutdinov and Kogan, 2000; Murakami, 1990). When applied to a GCM they are likely to underpredict the rate of rain formation as the cloud water content in the cloudy part of the grid box will be less than that in a CRM. I.e. the rates of rain and snow formation are often increased in GCMs as compared to CRMs (Pincus and Klein, 2000). The inhomogeneity factor refers to the fact that a plane-parallel cloud always reflects more sunlight back to space than an inhomogeneous cloud, (e.g. Barker, 1996; Carlin et al., 2002). Therefore the optical depth of ice clouds is reduced to take inhomogeneities into account. The entrainment rate into deep convective clouds controls how much environmental air is mixed into the updrafts. As the environmental air is normally drier and colder than the updraft, entrainment of environmental air reduces the buoyancy in the updraft and the updraft stops at lower altitudes. The default values of the tuning parameters at the used resolution and the range over which they have been systematically varied are summarized in Table 1 . In total we conducted 168 simulations in addition to the simulation using the default values of the tuning parameters.

\section{Present-day results}

The vertically integrated cloud liquid water mass mixing ratio (liquid water path), cloud ice mass mixing ratio (ice water path), specific humidity (water vapor mass) and total cloud cover as a function of the tuning parameter for the autoconversion rate $\gamma_{r}$ using the default value of the tuning parameter for the aggregation rate $\left(\gamma_{s}=800\right)$ in the climate simulations are shown in Fig. 1. Varying $\gamma_{r}$ primarily impacts the liquid water path. It is reduced from around $90 \mathrm{~g} \mathrm{~m}^{-2}$ to $40 \mathrm{~g} \mathrm{~m}^{-2}$ when increasing $\gamma_{r}$ from 1 to 10 . Changes in the entrainment rate and in the inhomogeneity factor of ice clouds are negligible for the liquid water path (Fig. 1). The observations of liquid water path are limited to the oceans. Only in the simulations with $\gamma_{r}=4$ and $\gamma_{r}=7$, the liquid water path over the ocean lies in within the observed range between 50 and $84 \mathrm{~g} \mathrm{~m}^{-2}$ (not shown). On the other hand, $\gamma_{r}$ has no influence on the ice water path and on the total precipitation rate and 
Table 1. Description, default values and the investigated values of the tuning parameters used in this study.

\begin{tabular}{llcc}
\hline $\begin{array}{l}\text { Tuning } \\
\text { parameter }\end{array}$ & Description & Default value & Investigated values \\
\hline$\gamma_{r}$ & autoconversion rate & 4 & $1,4,7,10$ \\
$\gamma_{s}$ & aggregation rate & 800 & $100,250,400,600,800,1000,1200$ \\
$\gamma_{i}$ & inhomogeneity factor of ice clouds & 0.75 & $0.7,0.9$ \\
$\epsilon$ & entrainment rate for deep convection $\left(\mathrm{kg} \mathrm{m}^{-3} \mathrm{~s}^{-1}\right)$ & $2 \times 10^{-4}$ & $1 \times 10^{-4}, 1.5 \times 10^{-4}, 2 \times 10^{-4}$ \\
\hline
\end{tabular}
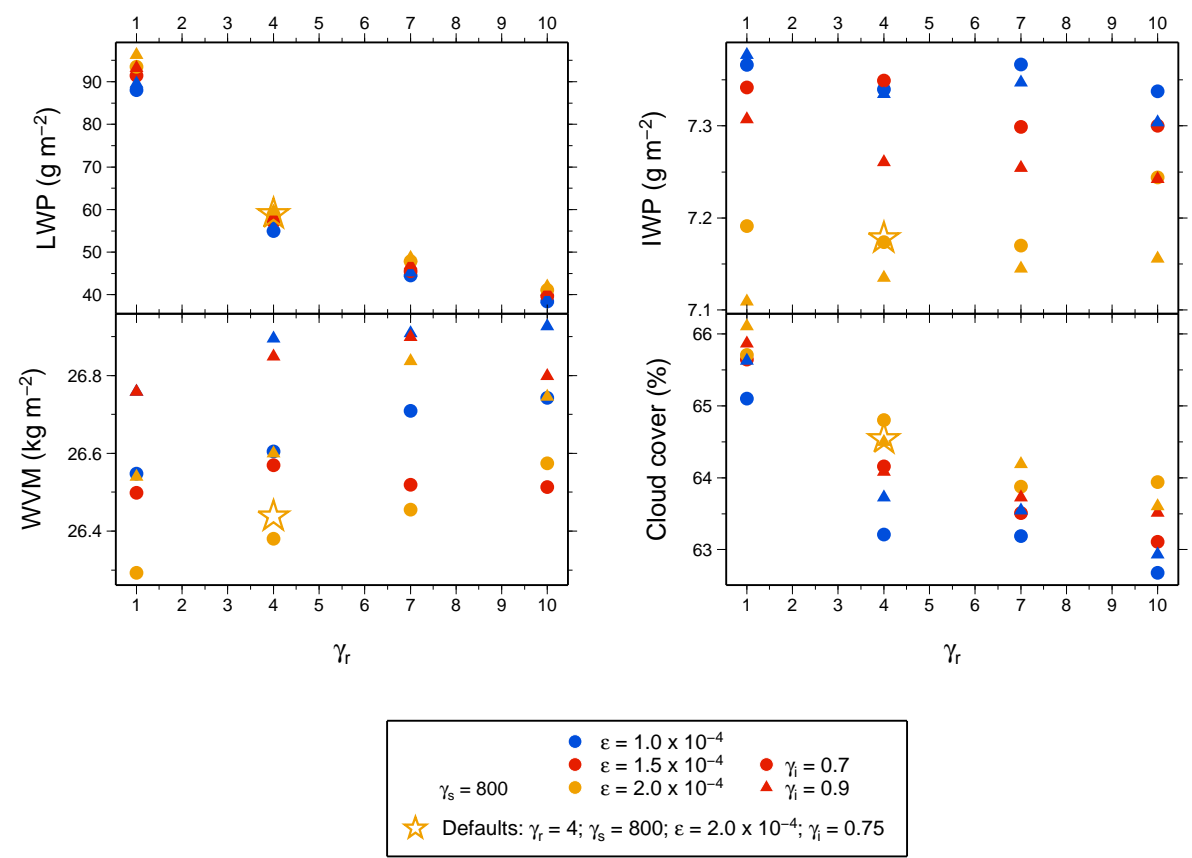

Fig. 1. Liquid water path (LWP), ice water path (IWP), water vapor mass (WVM) and total cloud cover as a function of $\gamma_{r}$ in the climate simulations.

only a small effect on the water vapor mass. The decrease in total cloud cover with increasing $\gamma_{r}$ stems from a reduction in low level clouds (not shown). All simulations fall in the range of total cloud cover between $62 \%$ and $67 \%$ obtained from surface observations (Hahn et al., 1994) and IPCC and MODIS satellite observations (Rossow and Schiffer, 1999; King et al., 2003) although newer satellite retrievals suggest the total cloud cover to be higher, between $65 \%$ and $75 \%$ (Stubenrauch et al., 2009). This would suggest that the simulations with $\gamma_{r}=1$ should be preferred. This is a contradiction to the results of the liquid water path where the simulations with a higher value of $\gamma_{r}$ yield better agreement with the observations.

The impact of varying $\gamma_{r}$ on the radiation balance is shown in Fig. 2. Because of the decrease in liquid water path with increasing $\gamma_{r}$, the shortwave cloud forcing becomes smaller with increasing $\gamma_{r}$. The decrease in longwave cloud forcing with increasing $\gamma_{r}$ is small because the ice water path is hardly influenced by $\gamma_{r}$ and the decrease in mid and high level cloud cover with increasing $\gamma_{r}$ is small (not shown).
The TOA radiation budget is balanced only for $\gamma_{r}=4$ and the highest value of the entrainment rate of deep convective clouds. For these simulations, the shortwave cloud forcing amounts to between -50 and $-52 \mathrm{~W} \mathrm{~m}^{-2}$ which is within $5 \mathrm{~W} \mathrm{~m}^{-2}$ of the observations if the ERBE satellite data of $-50 \mathrm{~W} \mathrm{~m}^{-2}$ (Kiehl and Trenberth, 1997) or ISCCP satellite data of $-51 \mathrm{~W} \mathrm{~m}^{-2}$ (Loeb et al., 2009) are used as a reference. However, they barely fall within $5 \mathrm{~W} \mathrm{~m}^{-2}$ of the observations if the CERES satellite estimate of $-46.6 \mathrm{~W} \mathrm{~m}^{-2}$ is considered (Loeb et al., 2009). The comparison of the longwave cloud forcing with satellite observations is even less straight forward as the observations vary between $22 \mathrm{~W} \mathrm{~m}^{-2}$ as deduced from the TOVS satellite (Susskind et al., 1997; Scott et al., 1999), $26.5 \mathrm{~W} \mathrm{~m}^{-2}$ from ISCCP (Loeb et al., 2009), $29.5 \mathrm{~W} \mathrm{~m}^{-2}$ from CERES (Loeb et al., 2009) and $30 \mathrm{~W} \mathrm{~m}^{-2}$ from ERBE (Kiehl and Trenberth, 1997). All simulated values fall within this range. In summary, the results suggest that overall the simulations using $\gamma_{r}=4$ are preferred because they match most observations. 

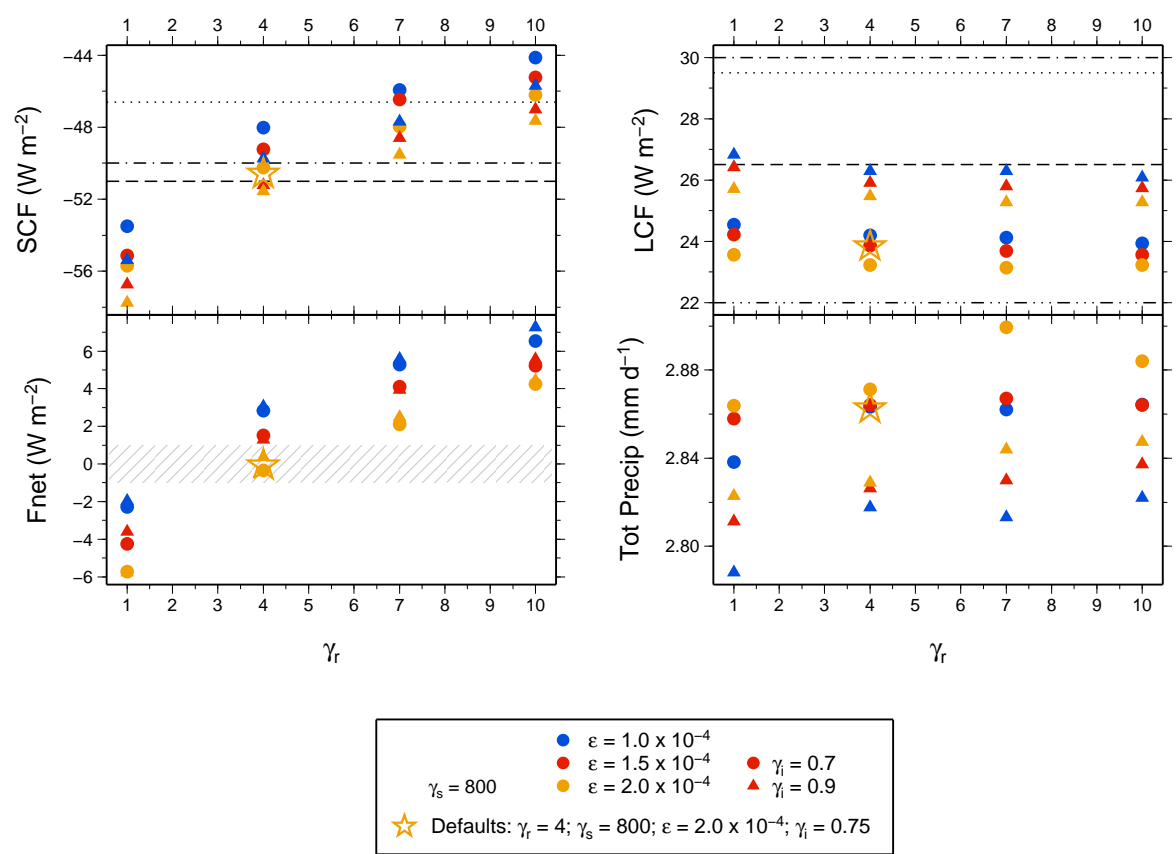

Fig. 2. Shortwave cloud forcing (SCF), longwave cloud forcing (LCF) and net radiation $\left(F_{\text {net }}\right)$ at the top-of-the-atmosphere and total precipitation as a function of $\gamma_{r}$ in the climate simulations. The observed estimates of the shortwave and longwave cloud forcing are shown as black lines (see text for details). The shaded area in the TOA net radiation refers to the desired range of $\pm 1 \mathrm{~W} \mathrm{~m}^{-2}$.

Figure 3 depicts the liquid and ice water path, water vapor mass and total cloud cover as a function of $\gamma_{s}$ using the default value of $\gamma_{r}=4$. As varying $\gamma_{s}$ primarily impacts the ice water path, it is reduced from about $22 \mathrm{~g} \mathrm{~m}^{-2}$ to $6 \mathrm{~g} \mathrm{~m}^{-2}$ when increasing $\gamma_{s}$ from 100 to 1200 . Varying the entrainment rate $\epsilon$ and the inhomogeneity factor of ice clouds $\gamma_{i}$ is negligible for the ice water path. Varying $\gamma_{s}$ has no systematic influence on the liquid water path and for all simulations the liquid water path over the oceans lies within the observed range (not shown). However, varying $\gamma_{r}$ and $\gamma_{s}$ strongly differs in that varying $\gamma_{s}$ affects the water vapor mass significantly, whereas varying $\gamma_{r}$ does not. This is discussed below. The decrease in water vapor mass with increasing $\gamma_{s}$ then leads to a larger decrease in total cloud cover than varying $\gamma_{r}$. Given that the newer observations of total cloud cover suggest that total cloud cover should be higher a smaller value of $\gamma_{s}$ is preferred.

Increasing $\gamma_{s}$ affects the latent heat and sensible heat fluxes whereas varying $\gamma_{r}$ has no systematic effect on the heat fluxes. An increase in $\gamma_{s}$ leads to a colder atmosphere everywhere. The relative humidity is increased in the upper troposphere but reduced near the surface. Thus, both the sensible and latent heat flux increase for larger values of $\gamma_{s}$ (not shown).

Increasing $\gamma_{s}$ also leads to a smaller shortwave and longwave cloud forcing (Fig. 4). The reduction in the shortwave cloud forcing is caused by the reduced ice water path and total cloud cover. As the cloud top pressure is not affected by changes in $\gamma_{s}$, the reduction in longwave cloud forcing is caused by the reduced ice water path and total cloud cover. The TOA radiation budget is balanced for different combinations of tuning parameters. It is balanced for $\gamma_{s}=400$, the highest value of $\epsilon$ and $\gamma_{i}=0.7$. For $\gamma_{s} \geq 600$, the TOA radiation is balanced for the highest value of $\epsilon$ irrespectively of $\gamma_{i}$. For the largest values of $\gamma_{s}(1000$ and 1200), even a smaller $\epsilon\left(1.5 \times 10^{-4} \mathrm{~kg} \mathrm{~m}^{-3} \mathrm{~s}^{-1}\right)$ combined with $\gamma_{i}=0.7$ leads to a TOA radiative balance within $1 \mathrm{~W} \mathrm{~m}^{-2}$. Because of the different observational estimates of the shortwave and longwave cloud forcing, we cannot conclude which of these combinations of the tuning parameters is the preferred one. However, if we take the observations of total cloud cover into account as well, a smaller value of $\gamma_{s}$ is preferred because in these simulations the total cloud cover is higher.

The ice water path and the total precipitation rate are influenced by the entrainment rate for deep convective clouds $\epsilon$ such that a larger value of $\epsilon$ implies less cloud ice. As more entrainment decreases the frequency of deep convection, less cloud ice is detrained. Also the convective precipitation decreases (not shown). Cloud water and ice that has not been converted into convective precipitation is detrained in the environment. The detrained cloud water and ice can be thought of the anvil of the convective cloud. The detrained cloud condensate is long-lived and of stratiform character. It is therefore added to the large-scale cloud water and ice. Thus, a decrease in the detrained cloud ice with increasing $\epsilon$ leads to a slightly reduced ice water path. Even though convective 

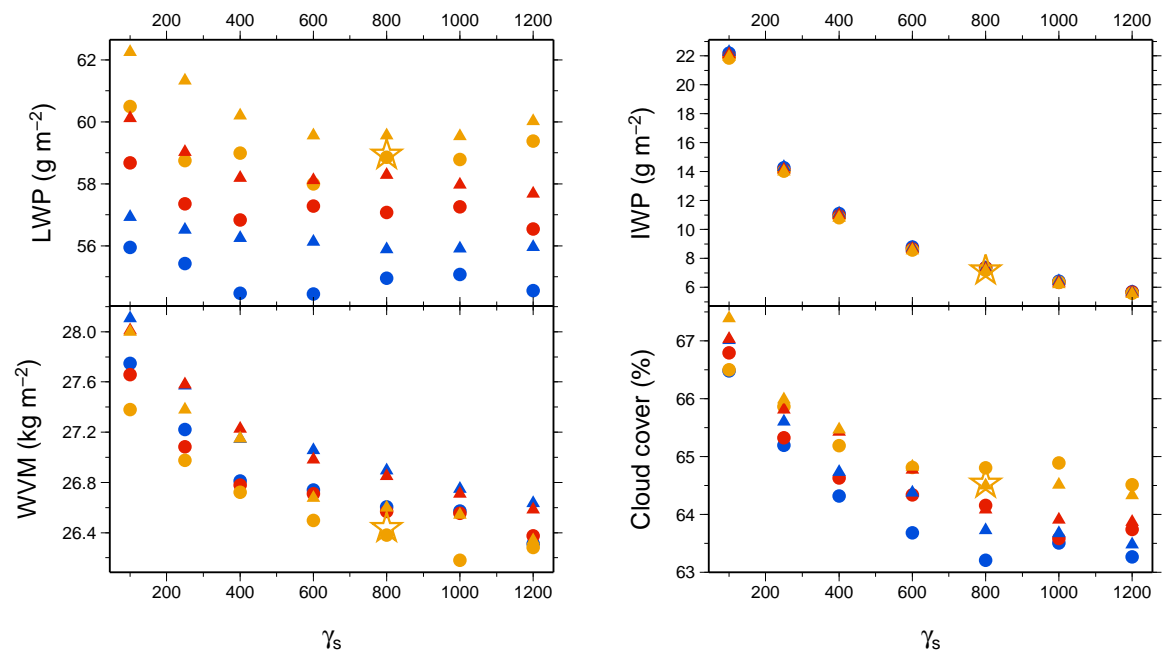

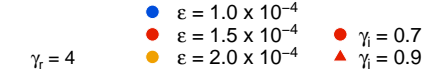

$$
\begin{aligned}
& \text { Defaults: } \gamma_{\mathrm{r}}=4 ; \gamma_{\mathrm{s}}=800 ; \varepsilon=2.0 \times 10^{-4} ; \gamma_{\mathrm{i}}=0.75
\end{aligned}
$$

Fig. 3. As Fig. 1 but as a function of $\gamma_{s}$.
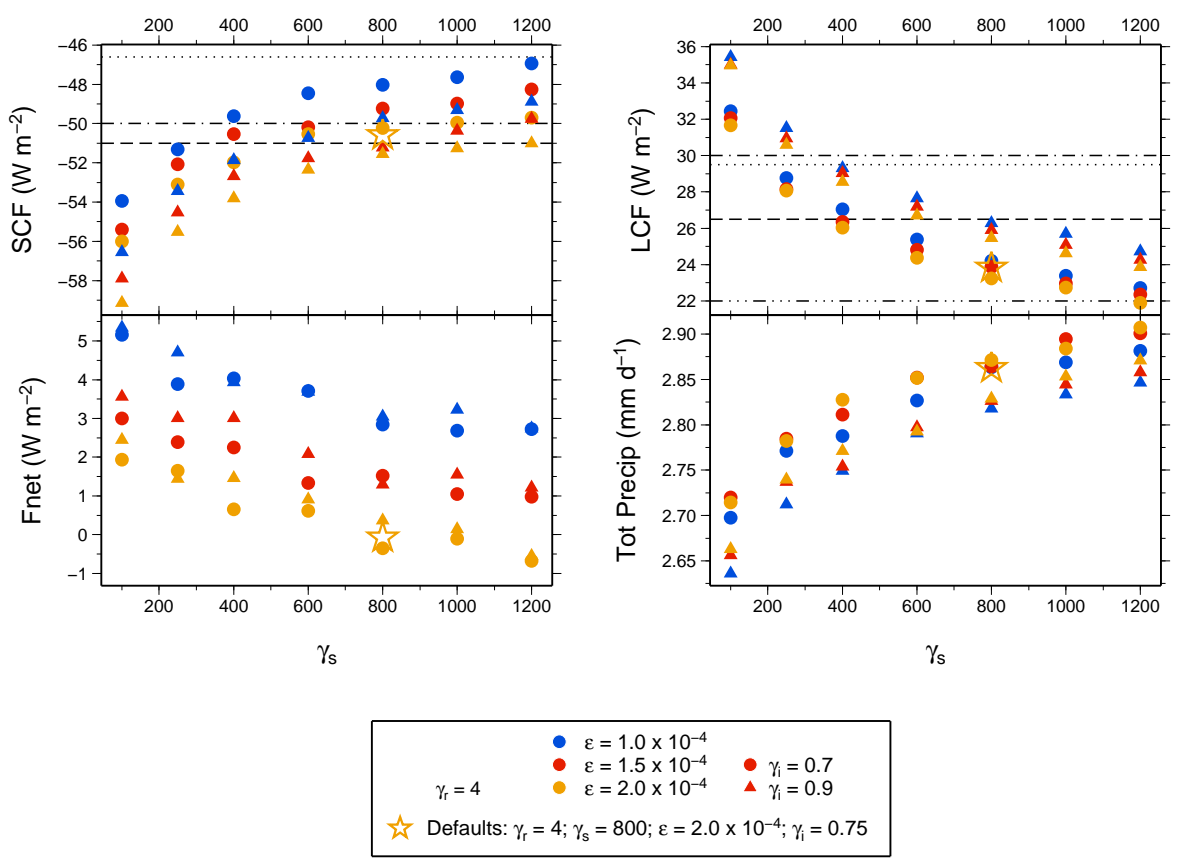

Fig. 4. As Fig. 4 but as a function of $\gamma_{s}$.

precipitation is decreased, the total precipitation slightly increases for a higher $\epsilon$ because more stratiform precipitation forms.

\section{Impact of tuning on the anthropogenic aerosol effect}

The importance of the tuning parameters on the total anthropogenic aerosol effect is shown in Fig. 5. The total anthropogenic aerosol effect is obtained from the difference 

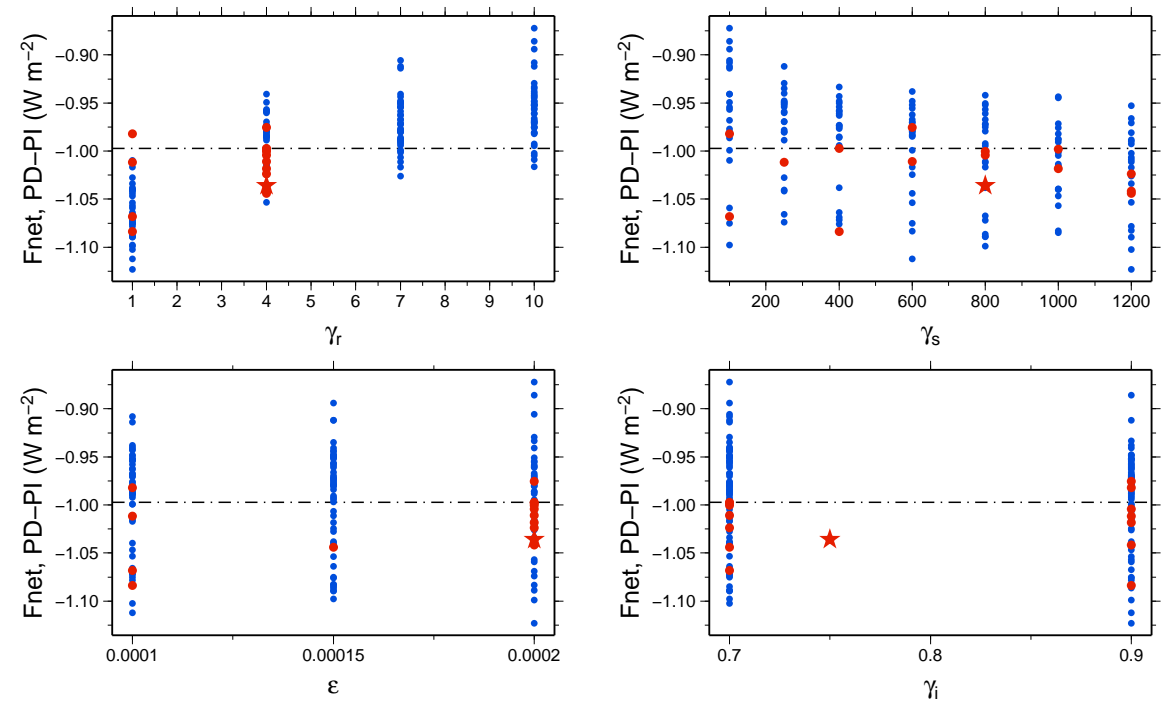

- All experiments (169)

- Experiments where radiative balance is achieved in free mode (15)

$\star$ Defaults: $\gamma_{\mathrm{r}}=4 ; \gamma_{\mathrm{s}}=800 ; \varepsilon=2.0 \times 10^{-4} ; \gamma_{\mathrm{i}}=0.75$

-.- Average

Fig. 5. Difference in the global annual mean net radiation at the top-of-the-atmosphere between pre-industrial times and the present day as a function of $\gamma_{r}$ (top left), $\gamma_{s}$ (top right), $\epsilon$ (bottom left) and $\gamma_{i}$ (bottom right) obtained from the nudged simulations.

in the TOA net radiation for the pre-industrial and presentday simulations. In this case, the nudged mode is used in order to keep the same meteorology while changing the emissions. The free simulations for which the radiative balance at TOA is within $\pm 1 \mathrm{~W} \mathrm{~m}^{-2}$ are highlighted as well. The average anthropogenic aerosol effect from all simulations is $-1.00 \mathrm{~W} \mathrm{~m}^{-2}$ as compared to $-1.02 \mathrm{~W} \mathrm{~m}^{-2}$ from those simulations where the global annual mean TOA radiation balance is within $\pm 1 \mathrm{~W} \mathrm{~m}^{-2}$. The values of the total anthropogenic aerosol effect in all simulations range from $-1.12 \mathrm{~W} \mathrm{~m}^{-2}$ to $-0.87 \mathrm{~W} \mathrm{~m}^{-2}$. This amounts to an uncertainty range of $25 \%$ between the minimum and the maximum value. This is comparable to the parametric uncertainties obtained by Haerter et al. (2009) although they used a much simpler estimate of the total anthropogenic aerosol effect being the sum of the direct effect and cloud albedo effect as estimated from monthly mean sulfate aerosol concentrations. Haerter et al. (2009), however, obtained a more negative estimate of the cloud albedo effect. Their estimate is comparable to earlier estimates with the ECHAM5 GCM (Lohmann et al., 2007). Since then we improved the cloud scheme in terms of the ice crystal fall velocity and ice crystal habit (Lohmann et al., 2008), and the aerosol scheme in terms of the water uptake, scavenging and nucleation (Lohmann and Hoose, 2009), all of which contributes to the lower estimate of the total anthropogenic aerosol effect in this study. The uncertainty range of the simulations with a balanced TOA radiation budget is reduced to $11 \%$, which constitutes a more rep- resentative estimate of the parametric uncertainty than taking all simulations into account.

The anthropogenic aerosol effect is smaller with increasing $\gamma_{r}$ because of the smaller liquid water paths for larger $\gamma_{r}$. The smaller liquid water path reduces the reflected shortwave radiation. In contrast, the anthropogenic aerosol effect increases very slightly when increasing $\gamma_{s}$ and there is no systematic change when increasing $\epsilon$ or $\gamma_{i}$. Thus tuning of the present-day climate does not seem to have an influence on the total anthropogenic aerosol effect.

\section{Conclusions}

In this paper we investigated the impact of key tuning parameters in the cloud scheme on the present-day climate and on the anthropogenic aerosol effect. The parametric uncertainty on the anthropogenic aerosol effect in terms of key aerosol processes has not been part of this study but was investigated e.g. by Penner et al. (2006). Moreover, there are other tuning parameters affecting the model climate outside the ones that are tested in this study. They are, for instance, associated with shallow convection, inhomogeneity of liquid water clouds, horizontal diffusion and launching of gravity waves. However, these parameters were never varied in the context of tuning the cloud microphysical scheme (Lohmann et al., 2007) and were therefore not investigated in this paper. 
In this study with the ECHAM5-HAM GCM we found that the impact of changing the tuning parameter for rain formation in stratiform clouds is limited to stratiform clouds. On the other hand, changing the tuning parameter for snow formation also affects convection. Increasing the snow formation rate leads to a cooling of the upper troposphere which enhances convective activity and convective precipitation. Changing the inhomogeneity of ice clouds was found to be of minor importance both for the present-day climate and for the total anthropogenic aerosol effect. These conclusions are limited to the ECHAM5-HAM GCM but such systematic studies may be useful for other GCMs as well.

The TOA radiation balance falls within $\pm 1 \mathrm{~W} \mathrm{~m}^{-2}$ for different combinations of the investigated tuning parameters. Because the different satellite estimates of the shortwave and longwave cloud forcing differ by 4 and $8 \mathrm{~W} \mathrm{~m}^{-2}$, respectively, the observations of the liquid water path of the oceans range between 50 to $84 \mathrm{~g} \mathrm{~m}^{-2}$ and the estimates of total cloud cover vary between 62 to $75 \%$, it is not possible to conclude which combination of tuning parameters is the best one.

The average total anthropogenic aerosol effect amounts to $-1.00 \mathrm{~W} \mathrm{~m}^{-2}$ from all simulations as compared to $-1.02 \mathrm{~W} \mathrm{~m}^{-2}$ from those simulations where the global annual mean TOA radiation balance is within $\pm 1 \mathrm{~W} \mathrm{~m}^{-2}$. These results suggest that the model tuning of the presentday climate does not seem to influence the total anthropogenic aerosol effect. The parametric uncertainty when taking all simulations into account is $25 \%$ as compared to $11 \%$ when only the simulations with a balanced TOA radiation budget are considered. This uncertainty is much smaller than the structural uncertainty between different models (Penner et al., 2006; Lohmann et al., 2010).

However, there are other parametric uncertainties. These include the uncertainty in parameters controlling aerosol processes, such as emissions, new particle formation, scavenging and the ability of aerosols to act as cloud condensation and ice nuclei. Some of these uncertain processes are evaluated in studies on structural uncertainties as different models apply different parameterizations. However, a parametric uncertainty including these processes is missing so far.

Acknowledgements. We like to acknowledge support by NCCR Climate and from the EU project EUCLIPSE (EU Cloud Intercomparison, Process Study \& Evaluation Project) No. 244067 and computer time from CSCS.

Edited by: E. Vignati

\section{References}

Abdul-Razzak, H. and Ghan, S. J.: A parameterization of aerosol activation: 2. Multiple aerosol types, J. Geophys. Res., 105, 6837-6844, 2000.

Barker, H. W.: A parameterization for computing grid-averaged solar fluxes for inhomogeneous marine boundary layer clouds. 1 . Methodology and homogeneous biases, J. Atmos. Sci., 53, 22892303, 1996.

Bauer, S. E., Wright, D. L., Koch, D., Lewis, E. R., McGraw, R., Chang, L.-S., Schwartz, S. E., and Ruedy, R.: MATRIX (Multiconfiguration Aerosol TRacker of mIXing state): an aerosol microphysical module for global atmospheric models, Atmos. Chem. Phys., 8, 6003-6035, doi:10.5194/acp-8-60032008, 2008.

Boucher, O. and Lohmann, U.: The sulfate-CCN-cloud albedo effect: A sensitivity study with two general circulation models, Tellus B, 47, 281-300, 1995.

Carlin, B., Fu, Q., Lohmann, U., Mace, G. G., Sassen, K., and Comstock, J. M.: High-cloud horizontal inhomogeneity and solar albedo bias, J. Climate, 15, 2321-2339, 2002.

Cox, P. and Stephenson, D.: Climate change - A changing climate for prediction, Science, 317, 207-208, 2007.

Croft, B., Lohmann, U., Martin, R. V., Stier, P., Wurzler, S., Feichter, J., Posselt, R., and Ferrachat, S.: Aerosol size-dependent below-cloud scavenging by rain and snow in the ECHAM5HAM, Atmos. Chem. Phys., 9, 4653-4675, doi:10.5194/acp-94653-2009, 2009.

Denman, K., Brasseur, G., Chidthaisong, A., Ciais, P., Cox, P., Dickinson, R., Hauglustaine, D., Heinze, C., Holland, E., Jacob, D., Lohmann, U., Ramachandran, S., Silva Dias, P., Wofsy, S., and Zhang, X.: Couplings between changes in the climate system and biogeochemistry, in: Climate Change 2007: The Physical Science Basis. Contribution of Working Group I to the Fourth Assessment Report of the Intergovernmental Panel on Climate Change, edited by: Solomon, S., Qin, D., Manning, M., Chen, Z., Marquis, M., Averyt, K. B., Tignor, M., and Miller, H. L., Cambridge Univ. Press, Cambridge, United Kingdom and New York, NY, USA, 499-588, 2007.

Dentener, F., Kinne, S., Bond, T., Boucher, O., Cofala, J., Generoso, S., Ginoux, P., Gong, S., Hoelzemann, J. J., Ito, A., Marelli, L., Penner, J. E., Putaud, J.-P., Textor, C., Schulz, M., van der Werf, G. R., and Wilson, J.: Emissions of primary aerosol and precursor gases in the years 2000 and 1750 prescribed data-sets for AeroCom, Atmos. Chem. Phys., 6, 4321-4344, doi:10.5194/acp6-4321-2006, 2006.

Ferraro, R., Weng, F., Grody, N., and Basist, A.: An Eight Year (1987-1994) Time Series of Rainfall, Clouds, Water Vapor, Snow-cover, and Sea-ice Derived from SSM/I Measurements, B. Am. Meteorol. Soc., 77, 891-905, 1996.

Forster, P., Ramaswamy, V., Artaxo, P., Berntsen, T., Betts, R., Fahey, D. W., Haywood, J., Lean, J., Lowe, D. C., Myhre, G., Nganga, J., Prinn, R., Raga, G., Schulz, M., and Van Dorland, R.: Radiative Forcing of Climate Change, in: Climate Change 2007: The Physical Science Basis. Contribution of Working Group I to the Fourth Assessment Report of the Intergovernmental Panel on Climate Change, edited by: Solomon, S., Qin, D., Manning, M., Chen, Z., Marquis, M., Averyt, K. B., Tignor, M., and Miller, H. L., Cambridge Univ. Press, Cambridge, United Kingdom and New York, NY, USA, 129-234, 2007. 
Fountoukis, C. and Nenes, A.: Continued development of a cloud droplet formation parameterization for global climate models, J. Geophys. Res., 110, D11212, doi:10.1029/2004JD005591, 2005.

Fowler, L. D., Randall, D. A., and Rutledge, S. A.: Liquid and ice cloud microphysics in the CSU general circulation model. Part I: Model description and simulated microphysical processes, J. Climate, 9, 489-529, 1996.

Ghan, S. J. and Easter, R. C.: Impact of cloud-borne aerosol representation on aerosol direct and indirect effects, Atmos. Chem. Phys., 6, 4163-4174, doi:10.5194/acp-6-4163-2006, 2006.

Ghan, S. J., Leung, L. R., Easter, R. C., and Abdul-Razzak, H.: Prediction of cloud droplet number in a general circulation model, J. Geophys. Res., 102, 21777-21794, 1997a.

Ghan, S. J., Leung, L. R., and Hu, Q.: Application of cloud microphysics to NCAR community climate model, J. Geophys. Res., 102, 16507-16527, 1997b.

Greenwald, T. J., Stephens, G. L., Vonder Haar, T. H., and Jackson, D. L.: A Physical Retrieval of Cloud Liquid Water Over the Global Oceans Using Special Sensor Microwave/Imager (SSM/I) Observations, J. Geophys. Res., 98, 18471-18488, 1993.

Haerter, J. O., Roeckner, E., Tomassini, L., and von Storch, J. S.: Parametric uncertainty effects on aerosol radiative forcing, Geophys. Res. Lett., 36, L15707, doi:10.1029/2009GL039050, 2009.

Hahn, C. J., Warren, S. G., and London, J.: Climatological data for clouds over the globe from surface observations, 1982-1991: The total cloud edition, Tech. rep., ORNL/CDIAC-72 NDP-026A Oak Ridge National Laboratory, Oak Ridge Tennessee, USA, 1994.

Hansen, J., Nazarenko, L., Ruedy, R., Sato, M., Willis, J., Del Genio, A., Koch, D., Lacis, A., Lo, K., Menon, S., Novakov, T., Perlwitz, J., Russell, G., Schmidt, G. A., and Tausnev, N.: Earth's energy imbalance: Confirmation and implications, Science, 308, 1431-1435, 2005.

Hawkins, E. and Sutton, R.: The Potential to Narrow Uncertainty in Regional Climate Predictions, B. Am. Meteorol. Soc., 90, 10951107, 2009.

Hoose, C., Lohmann, U., Erdin, R., and Tegen, I.: Global influence of dust mineralogical composition on heterogeneous ice nucleation in mixed-phase clouds, Environ. Res. Lett., 3, 025003, doi:10.1088/1748-9326/3/2/025003, 2008b.

Jones, A., Roberts, D. L., Woodage, M. J., and Johnson, C. E.: Indirect sulphate aerosol forcing in a climate model with an interactive sulphur cycle, J. Geophys. Res., 106, 20293-20310, 2001.

Kärcher, B. and Ström, J.: The roles of dynamical variability and aerosols in cirrus cloud formation, Atmos. Chem. Phys., 3, 823 838, doi:10.5194/acp-3-823-2003, 2003.

Kazil, J. and Lovejoy, E. R.: A semi-analytical method for calculating rates of new sulfate aerosol formation from the gas phase, Atmos. Chem. Phys., 7, 3447-3459, doi:10.5194/acp-7-3447-2007, 2007.

Khairoutdinov, M. and Kogan, Y.: A new cloud physics parameterization in a large-eddy simulation model of marine stratocumulus, Mon. Weather Rev., 128, 229-243, 2000.

Kiehl, J. T. and Trenberth, K. E.: Earth's Annual Global Mean Energy Budget, B. Am. Meteorol. Soc., 78, 197-208, 1997.

King, M. D., Menzel, W. P., Kaufman, Y. J., Tanre, D., Gao, B. C., Platnick, S., Ackerman, S. A., Remer, L. A., Pincus, R., and Hubanks, P. A.: Cloud and aerosol properties, precipitable water, and profiles of temperature and water vapor from MODIS, IEEE
T. Geosci. Remote, 41, 442-458, 2003.

Koch, D., Menon, S., Del Genio, A., Ruedy, R., Aleinov, I., and Schmidt, G. A.: Distinguishing aerosol impacts on climate over the past century, J. Climate, 22, 2659-2677, 2009.

Loeb, N. G., Wielicki, B. A., Doelling, D. R., Smith, G. L., Keyes, D. F., Kato, S., Manalo-Smith, N., and Wong, T.: Toward Optimal Closure of the Earth's Top-of-Atmosphere Radiation Budget, J. Climate, 22, 748-766, 2009

Lohmann, U. and Diehl, K.: Sensitivity studies of the importance of dust ice nuclei for the indirect aerosol effect on stratiform mixedphase clouds, J. Atmos. Sci, 63, 968-982, 2006.

Lohmann, U. and Hoose, C.: Sensitivity studies of different aerosol indirect effects in mixed-phase clouds, Atmos. Chem. Phys., 9, 8917-8934, doi:10.5194/acp-9-8917-2009, 2009.

Lohmann, U. and Roeckner, E.: Design and performance of a new cloud microphysics scheme developed for the ECHAM general circulation model, Clim. Dyn., 12, 557-572, 1996.

Lohmann, U., Stier, P., Hoose, C., Ferrachat, S., Kloster, S., Roeckner, E., and Zhang, J.: Cloud microphysics and aerosol indirect effects in the global climate model ECHAM5-HAM, Atmos. Chem. Phys., 7, 3425-3446, doi:10.5194/acp-7-3425-2007, 2007.

Lohmann, U., Spichtinger, P., Jess, S., Peter, T., and Smit, H.: Cirrus cloud formation and ice supersaturated regions in a global climate model, Environ. Res. Lett., 3, 045022, doi:10.1088/17489326/3/4/045022, 2008.

Lohmann, U., Rotstayn, L., Storelvmo, T., Jones, A., Menon, S., Quaas, J., Ekman, A. M. L., Koch, D., and Ruedy, R.: Total aerosol effect: radiative forcing or radiative flux perturbation?, Atmos. Chem. Phys., 10, 3235-3246, doi:10.5194/acp-10-32352010, 2010.

Meehl, G. A., Stocker, T. F., Collins, W. D., Friedlingstein, P., Gaye, A. T., Gregory, J. M., Kitoh, A., Knutti, R., Murphy, J. M., Noda, A., Raper, S. C. B., Watterson, I. G., Weaver, A. J., and Zhao, Z.-C.: Global climate projections, in: Climate Change 2007: The Physical Science Basis. Contribution of Working Group I to the Fourth Assessment Report of the Intergovernmental Panel on Climate Change, edited by: Solomon, S., Qin, D., Manning, M., Chen, Z., Marquis, M., Averyt, K. B., Tignor, M., and Miller, H. L., Cambridge Univ. Press, Cambridge, United Kingdom and New York, NY, USA, 747-846, 2007.

Ming, Y., Ramaswamy, V., Donner, L. J., and Phillips, V. T. J.: A new parameterization of cloud droplet activation applicable to general circulation models, J. Atmos. Sci., 63, 1348-1356, 2006.

Ming, Y., Ramaswamy, V., Donner, L. J., Phillips, V. T. J., Klein, S. A., Ginoux, P. A., and Horowitz, L. W.: Modeling the interactions between aerosols and liquid water clouds with a selfconsistent cloud scheme in a general circulation model, J. Atmos. Sci., 64, 1189-1209, 2007.

Morrison, H. and Gettelman, A.: A new two-moment bulk stratiform cloud microphysics scheme in the community atmosphere model, version 3 (CAM3). Part I: Description and numerical tests, J. Climate, 21, 3642-3659, 2008.

Murakami, M.: Numerical Modeling of Dynamic and Microphysical Evolution of an Isolated Convective Cloud - the 19 July 1981 Ccope Cloud, J. Meteorol. Soc. Japan, 68, 107-128, 1990.

Murphy, J. M., Sexton, D. M. H., Barnett, D. N., Jones, G. S., Webb, M. J., and Collins, M.: Quantification of modelling uncertainties in a large ensemble of climate change simulations, Nature, 430 , 
768-772, 2004.

Pan, W., Tatang, M. A., McRae, G. J., and Prinn, R. G.: Uncertainty analysis of indirect radiative forcing by anthropogenic sulfate aerosols, J. Geophys. Res., 103, 3815-3823, 1998.

Penner, J. E., Quaas, J., Storelvmo, T., Takemura, T., Boucher, O., Guo, H., Kirkevåg, A., Kristjánsson, J. E., and Seland, Ø.: Model intercomparison of indirect aerosol effects, Atmos. Chem. Phys., 6, 3391-3405, doi:10.5194/acp-6-3391-2006, 2006.

Petters, M. D. and Kreidenweis, S. M.: A single parameter representation of hygroscopic growth and cloud condensation nucleus activity, Atmos. Chem. Phys., 7, 1961-1971, doi:10.5194/acp-71961-2007, 2007.

Piani, C., Frame, D. J., Stainforth, D. A., and Allen, M. R.: Constraints on climate change from a multi-thousand member ensemble of simulations, Geophys. Res. Lett., 32, L23825, doi:10.1029/2005GL024452, 2005.

Pincus, R. and Klein, S. A.: Unresolved spatial variability and microphysical process rates in large scale models, J. Geophys. Res., 105, 27059-27065, 2000

Pringle, K. J., Carslaw, K. S., Spracklen, D. V., Mann, G. M., and Chipperfield, M. P.: The relationship between aerosol and cloud drop number concentrations in a global aerosol microphysics model, Atmos. Chem. Phys., 9, 4131-4144, doi:10.5194/acp-94131-2009, 2009.

Rossow, W. B. and Schiffer, R. A.: Advances in understanding clouds from ISCCP, B. Am. Meteorol. Soc., 80, 2261-2287, 1999.

Rotstayn, L. D., Cai, W. J., Dix, M. R., Farquhar, G. D., Feng, Y., Ginoux, P., Herzog, M., Ito, A., Penner, J. E., Roderick, M. L., and Wang, M. H.: Have Australian rainfall and cloudiness increased due to the remote effects of Asian anthropogenic aerosols?, J. Geophys. Res., 112, D09202, doi:10.1029/2006JD007712, 2007.

Salzmann, M., Ming, Y., Golaz, J.-C., Ginoux, P. A., Morrison, H., Gettelman, A., Krmer, M., and Donner, L. J.: Two-moment bulk stratiform cloud microphysics in the GFDL AM3 GCM: description, evaluation, and sensitivity tests, Atmos. Chem. Phys., 10, 8037-8064, doi:10.5194/acp-10-8037-2010, 2010.

Scott, N. A., Chedin, A., Armante, R., Francis, J., Stubenrauch, C., Chaboureau, J. P., Chevallier, F., Claud, C., and Cheruy, F.: Characteristics of the TOVS Pathfinder Path-B dataset, B. Am. Meteorol. Soc., 80, 2679-2701, 1999.
Simmons, A. J. and Gibson, J. K.: The ERA-40 project plan., Tech. rep., ECMWF, Shinfield Park, Reading, UK, 2000.

Stier, P., Feichter, J., Kinne, S., Kloster, S., Vignati, E., Wilson, J., Ganzeveld, L., Tegen, I., Werner, M., Balkanski, Y., Schulz, M., Boucher, O., Minikin, A., and Petzold, A.: The aerosolclimate model ECHAM5-HAM, Atmos. Chem. Phys., 5, 11251156, doi:10.5194/acp-5-1125-2005, 2005.

Storelvmo, T., Kristjánsson, J.-E., and Lohmann, U.: Aerosol influence on mixed-phase clouds in CAM-Oslo, J. Atmos. Sci., 65 , 3214-3230, 2008.

Storelvmo, T., Lohmann, U., and Bennartz, R.: What governs the spread in shortwave forcings in the transient IPCC AR4 models?, Geophys. Res. Lett., 36, L01806, doi:10.1029/2008GL036069, 2009.

Stubenrauch, C., Kinne, S., and GEWEX Clouc Assessment Team: Assessment of Global Cloud Climatologies, in GEWEX newsletter, vol. 19, GEWEX, 2009.

Sundqvist, H., Berge, E., and Kristjánsson, J. E.: Condensation and Cloud Parameterization Studies with a Mesoscale Numerical Weather Prediction Model, Mon. Weather Rev., 117, 1641-1657, 1989.

Susskind, J., Piraino, P., Rokke, L., Iredell, T., and Mehta, A.: Characteristics of the TOVS Pathfinder Path A dataset, B. Am. Meteorol. Soc., 78, 1449-1472, 1997.

Suzuki, K., Nakajima, T., Satoh, M., Tomita, H., Takemura, T., Nakajima, T. Y., and Stephens, G. L.: Global cloud-systemresolving simulation of aerosol effect on warm clouds, Geophys. Res. Lett., 35, L19817, doi:10.1029/2008GL035449, 2008

Takemura, T., Nozawa, T., Emori, S., Nakajima, T. Y., and Nakajima, T.: Simulation of climate response to aerosol direct and indirect effects with aerosol transport-radiation model, J. Geophys. Res., 110, D02202, doi:10.1029/2004JD00502, 2005.

Twomey, S. A.: The influence of pollution on the shortwave albedo of clouds, J. Atmos. Sci., 34, 1149-1152, 1977.

Wang, M. and Penner, J. E.: Aerosol indirect forcing in a global model with particle nucleation, Atmos. Chem. Phys., 9, 239-260, doi:10.5194/acp-9-239-2009, 2009.

Weng, F. and Grody, N. C.: Retrieval of cloud liquid water using the special sensor microwave imager (SSM/I), J. Geophys. Res., 99, 25535-25551, 1994. 